\title{
Economic Analysis of Ginseng Based Forest Farming: a Sustainable Income Diversification Opportunity for Forest Landowners
}

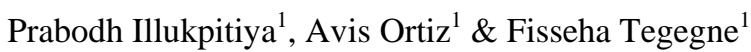 \\ ${ }^{1}$ Department of Agricultural and Environmental Sciences, Tennessee State University, 3500 John A. Merritt \\ Blvd, Nashville Tennessee 37209, USA \\ Correspondence: Prabodh Illukpitiya, Department of Agricultural and Environmental Sciences, Tennessee State \\ University, 3500 John A. Merritt Blvd, Nashville Tennessee 37209, USA. Tel: 615-963-1877. E-mail: \\ pillukpi@tnstate.edu
}

Received: June 4, 2021 Accepted: August 7, 2021 Online Published: January 12, 2022

doi:10.5539/sar.v11n1p25

URL: https://doi.org/10.5539/sar.v11n1p25

\begin{abstract}
While American ginseng is a complicated opportunity for forest farmers to understand, within these production systems there are many opportunities and constraints linked to production of ginseng. There are different market demands and prices paid for the various grades of dried roots depending on the system used to cultivate the plant. This study reviewed the unique benefits of producing ginseng, opportunities for forest farmers, the potential profits, as well as financial risks. The study focused on two common ginseng production systems in the southeastern region of the U.S. The specific objective of the paper is to assess economic returns of producing ginseng under different production systems. The Monte Carlo simulation was performed to analyze the profitability and risks associated with producing ginseng and performed sensitive analysis to determine the effect of uncertainty variables such as production costs, yield, and price of product on economic feasibility.
\end{abstract}

Keywords: economic returns, forest farming, ginseng, income diversification, Monte Carlo simulation, sensitivity analysis

\section{Introduction}

American ginseng (Panax quinquefolius L.) is indigenous to the southern portions of Ontario and Quebec in Canada and deciduous forests in the mid-western, southern and eastern parts of the United States (Cheng and Mitchell, 2009; Punja, 2011). American ginseng has been cultivated in the U.S. since the late 1800's and also grown in ginseng farms (Beyfuss, 1999; USFWS, n.d). Ginseng is being distributed in 35 countries around the world and there are differences by each country in the distribution volume and amount (Baeg and So, 2013). While cultivation of this plant species has taken place in North America for over 100 years, there are many challenges that need to be addressed. While ginseng is native to eastern North America, major producers of wild ginseng thrive along most of the nation's eastern seaboard, from Maine to Alabama and west to Michigan, Wisconsin and Minnesota. It still grows wild, but it was over-harvested and was subsequently defined as an endangered species in 1975 (Harrison et al., 2015; USFWS n.d; Vaughn et al., 2011).

Ginseng is unique in its several benefits for a range of health conditions.Its roots have many benefits such as helps in weight loss, preventing and managing diabetes, reduce stress and anxiety etc. Moreover, growing ginseng promises lucrative financial for the growers (Maher, 2014). For example, given favorable climatic conditions and with little capital investment, it is possible to gain up to $\$ 26,880$ worth of the prized botanical on only 0.2 ha (about half an acre) woodland in 10 year cycle (Ha et al., 2017). For generations, Appalachian residents have harvested ginseng roots as a source of extra income (Hankins, 2014). Often, whole families would search the woods each fall for the distinctive three or four-pronged plant and the lucrative roots lying beneath its yellow leaves (Axtell, 2012).Ginseng is so prized for its medicinal properties that poaching and overharvesting of the plant by collectors threatens to wipe out wild Appalachian ginseng from North Carolina's forests and dried roots sell for $\$ 1,100-\$ 1,320 / \mathrm{kg}$ (Axtel, 2012). Ginseng is one of the most popular holiday gifts in China. American ginseng is stamped with a 100\% guarantee. Few consumers are more faithful to American products than Chinese users of ginseng: The U.S. exported \$77.3 million in ginseng roots in year 2014, most of it to Hong Kong, and American ginseng fetches the highest price of any cultivated variety (Shyong, 2015).

According to the U.S. Department of Commerce, US has long history of exporting dried wild ginseng roots. 
While American ginseng is a "complicated opportunity for forest farmers to understand, it can be grown in many different production systems" (Wallin, 2016). Within these production systems there are many opportunities and constraints linked to this plant. There are different market demands and prices paid for the different grades of the dried roots depending on the system used to cultivate the plant. This could provide an opportunity to learn about forest income enterprises other than timber (Wallin, 2016). Also in a survey among landowners in the southern US, nearly forty percent indicated a desire for more information on forest farming (Workman et al., 2003), and over half of the extension agents and almost 30 percent of foresters in the Mid-Atlantic states have been queried by landowners about ginseng income opportunities (Kays, 2004). Considering the above facts, the major objective of this paper is to analyze economic returns of producing ginseng under natural production systems and to determine the effect of uncertainty variables on net return using Monte Carlo simulation.

\section{Methodology}

Given the different systems of ginseng production, evaluation of profitability from each system is important for producers to identify the most appropriate choice that provide them highest income. Therefore, the economic analysis is mainly focused on the producer's point of view concerning ginseng root production under two different systems. This information is also useful for potential forest land owners who are interested in identifying least cost production system that gives highest net return in ginseng production. In ginseng, the cost of production includes commonly used cost categories from land preparation to harvesting and drying. The analysis assumes that ginseng production is on own land hence rental costs were excluded from the analysis. It should be noted that certain field operations are not performed regularly and uniformly year after year, therefore, annual costs may differ over the crop's life. From an economic point of view, the overall approach is to estimate range of outcome give various input distributions. Rational economic decision-makers are assumed to make crop production decisions by choosing crop that maximize their profits under risk and uncertainty. The landowner's overall objective is to maximize profit, which is the net return from selected enterprise. The profit function $\left(\pi_{j}\right)$ can be represented by (Yuldashev et al., 2020):

$$
\pi_{\mathrm{j}}=\Sigma\left[\left(\mathrm{P}_{\mathrm{j}} * \mathrm{Y}_{\mathrm{j}}\right)-\left(\mathrm{Q}_{\mathrm{j}} * \mathrm{P}_{\mathrm{Ij}}\right)-\mathrm{FC}_{\mathrm{j}}\right]
$$

Where $\pi_{j}$ represents profit of $\mathrm{j}^{\text {th }}$ ginseng producer $\left(\$ / \mathrm{ha} \mathrm{yr}^{-1}\right), Y_{j}$ represents yield of ginseng for the $\mathrm{j}^{\text {th }}$ producer $\left(\mathrm{kg} / \mathrm{ha} \mathrm{yr}{ }^{-1}\right), P_{j}$ represents selling price of ginseng for the $\mathrm{j}^{\text {th }}$ producer $(\$ / \mathrm{kg}), Q_{j}$ represents variable inputs applied during ginseng production such as labor for various field operations, seed, soil amendments, fertilizer, other agrochemicals; $P_{I j}$ represents price of the $j^{\text {th }}$ input applied for ginseng production. For example, $\Sigma\left(Q_{j} * P_{I j}\right)$ represent total variable costs of production and $F C_{\mathrm{j}}$ represents total fixed cost. Based on our data, we identified range of values for input costs, price and biomass yield, just like the triangular distribution. However, the triangular distribution may place too much emphasis on the most likely value, at the expense of the values to either side hence is limited in its ability to model real-world estimates (Palisade, n.d). Therefore we used pert distribution which is designed to generate a distribution that more closely resembles realistic probability distribution. The pert distribution constructs a smooth curve which places progressively more emphasis on values around (near) the most likely value, in favor of values around the edges. Given that many real-world phenomena are normally distributed, the pert distribution produces a curve similar to the normal curve. Depending on the values provided, the pert distribution can provide a close fit to the normal or lognormal distributions. Range of net returns were calculated based on random samples obtained from yield-price-cost distributions with the help of Monte Carlo simulation (Arnold and Yildiz, 2015; Sgroiet al., 2015). In Monte Carlo simulation, uncertain inputs (such as input costs, yield and price) in a model are represented using ranges of possible values known as probability distributions. By using probability distributions, variables can have different probabilities of different outcomes (net return) occurring. Probability distributions are a much more realistic way of describing uncertainty in variables of a risk analysis. The sensitivity analysis was performed to evaluate the effect of uncertain variables in net return.

Given limited availability of production data of ginseng, we usedmulti-method approach which encourages collecting, analyzing and integrating data from several sources. The data collected represented the different types and methods for producing ginseng mainly wood cultivated and wild simulated. Data was collected from published reports, enterprise budgets from University Extension services and producer survey.The data collected was focused on input costs from land preparation up to harvesting and drying, ginseng yields and market prices of ginseng. Specifically production data included costs for seed, labor, fertilizer, other agrochemicals, equipment such as back pack sprayers, drying equipment, security cameras etc. Market prices were used to estimate input costs of the different types of ginseng. Based on the literature, production cycle for woods-cultivated ginseng was considered as 6-8 years, and wild-simulated ginseng as 7-12 years. The data showed that the cost of production varies with quality and quantity, and form year to year based on supply and demand. 
The analysis was based on the notion that average figures do not reflect range of outcome; therefore, there is a need to assess the uncertainty of variables to be identified and considered for possible range of net return under various scenarios for ginseng production. Monte Carlo simulation was performed using risk analysis software (@Risk) to measure range of outcomes by incorporating uncertainty function based on random samples generated. Monte Carlo simulation generates large number of random samples and estimate true mean, which is the average of net profit across large number of random samples.

\section{Results}

The results of the Monte Carlo simulation for wood cultivated and wild simulated ginseng production systems are discussed below.

\subsection{Wood Cultivated Ginseng}

Figure 1-3 shows input distribution of wood cultivated ginseng. Accordingly, within $90 \%$ confidence interval, estimated yield of the wood cultivated ginseng range from $699-783 \mathrm{~kg} / \mathrm{ha}$ with the mean yield of $741 \mathrm{~kg} / \mathrm{ha}$. The minimum potential yield was $675 \mathrm{~kg} / \mathrm{ha}$ and the maximum potential yield was $807 \mathrm{~kg} / \mathrm{ha}$. There is a $90 \%$ probability that the selling price will range from $\$ 241-\$ 309 / \mathrm{kg}$. Also under $90 \%$ confidence interval, the estimated unit cost of the wood cultivated ginseng ranges from $\$ 77-\$ 137 / \mathrm{kg}$. The minimum potential unit cost per cycle was $\$ 71 / \mathrm{kg}$ and the maximum cost was $\$ 173 / \mathrm{kg}$ with the mean of $\$ 103 / \mathrm{kg}$.

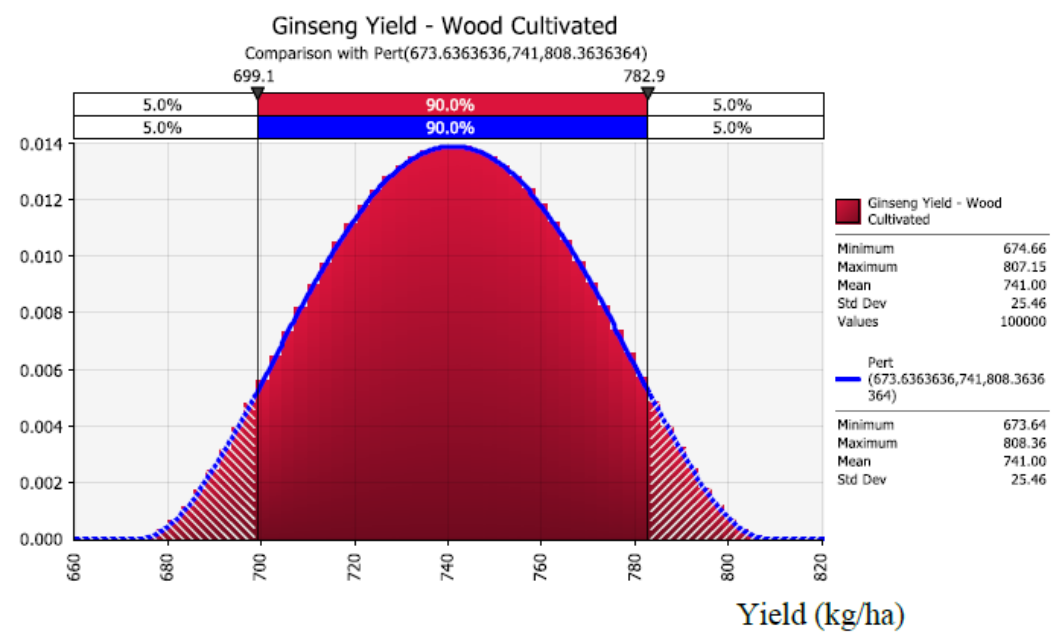

Figure 1. Potential yield distribution of wood cultivated ginseng

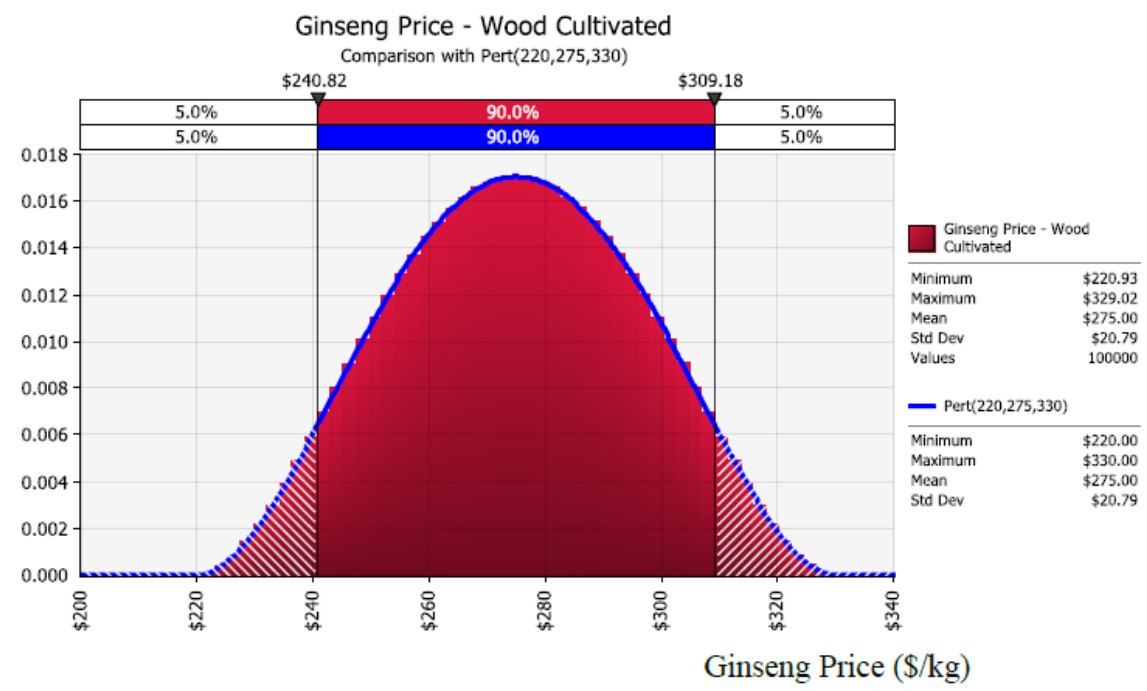

Figure 2. Potential price distribution of wood cultivated ginseng 


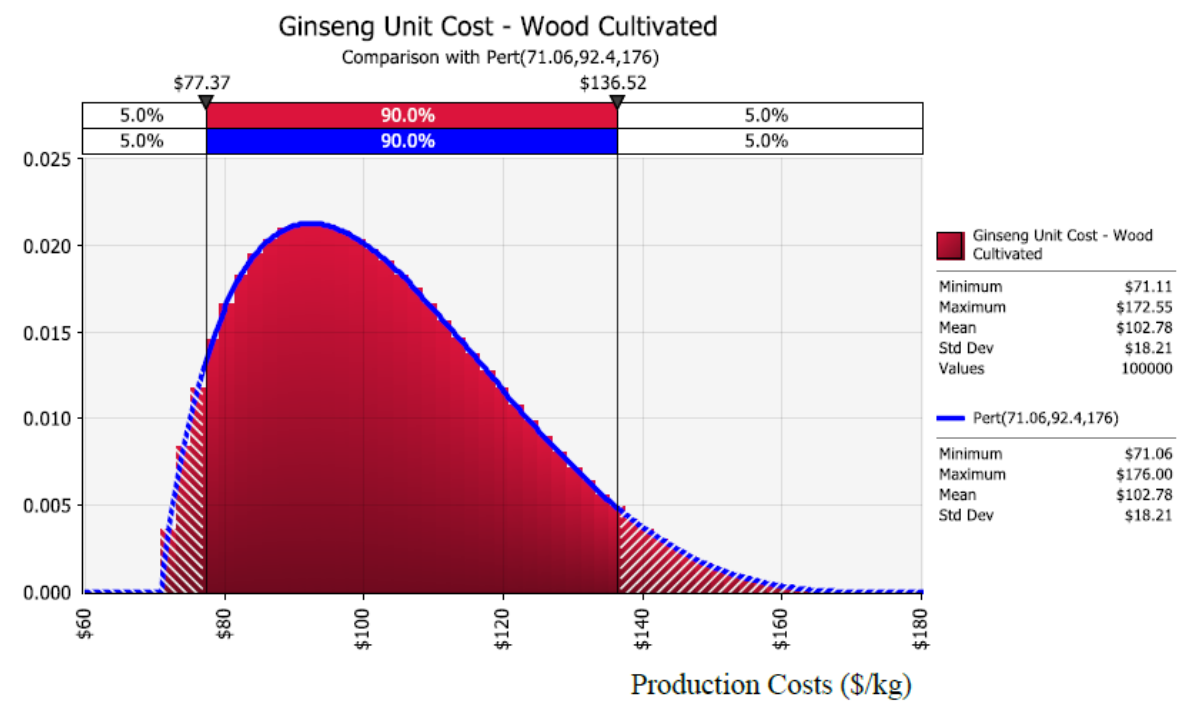

Figure 3. Potential unit cost distribution of wood cultivated ginseng

Figure 4 shows the net profit for wood cultivated ginseng, accordingly, there is high probability (0.90) that the net profit will range from $\$ 89,682$ - $\$ 158,624 /$ cycle. The estimated minimum potential net profit was $\$ 48,966$ and the maximum net profit was $\$ 192,006$ with the mean of $\$ 124,816 /$ cycle.



Figure 4. Distribution of net return from wood cultivated ginseng

Figure 5 shows the correlation between ginseng yield, price and unit cost to net profit. The Tornado graph (Figure 6) shows the general trend of the association between key risk variables with net return from feedstock production (Figure 5). The longer the bar or the larger the coefficient, the greater the impact that particular input has on the net return. For example, the unit production costs (\$/ha) show inverse (negative) relationship with profit while ginseng yield and price show a positive relationship with net return. In tornado graph, the regression coefficients doesn't express them in terms of actual dollar value. They are scaled or normalized by the standard deviation of the output and the standard deviation of that input. For example, regression coefficient of selling price of ginseng was 0.73 . This means that for every $\mathrm{k}$ fraction of a standard deviation (SD) increase in selling price, the net return will increase by $0.73 \mathrm{k}$ standard deviations. To get from that coefficient to the actual coefficient in terms of unit of price and unit of net return, we need to multiply by the SD of the net return and divide by the SD of the price. 

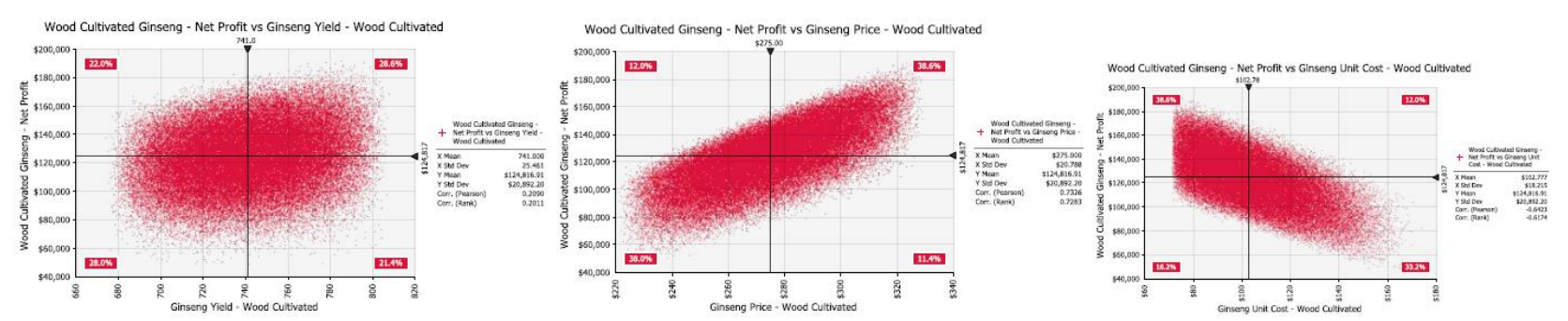

Figure 5. Correlation between net return and stochastic variables

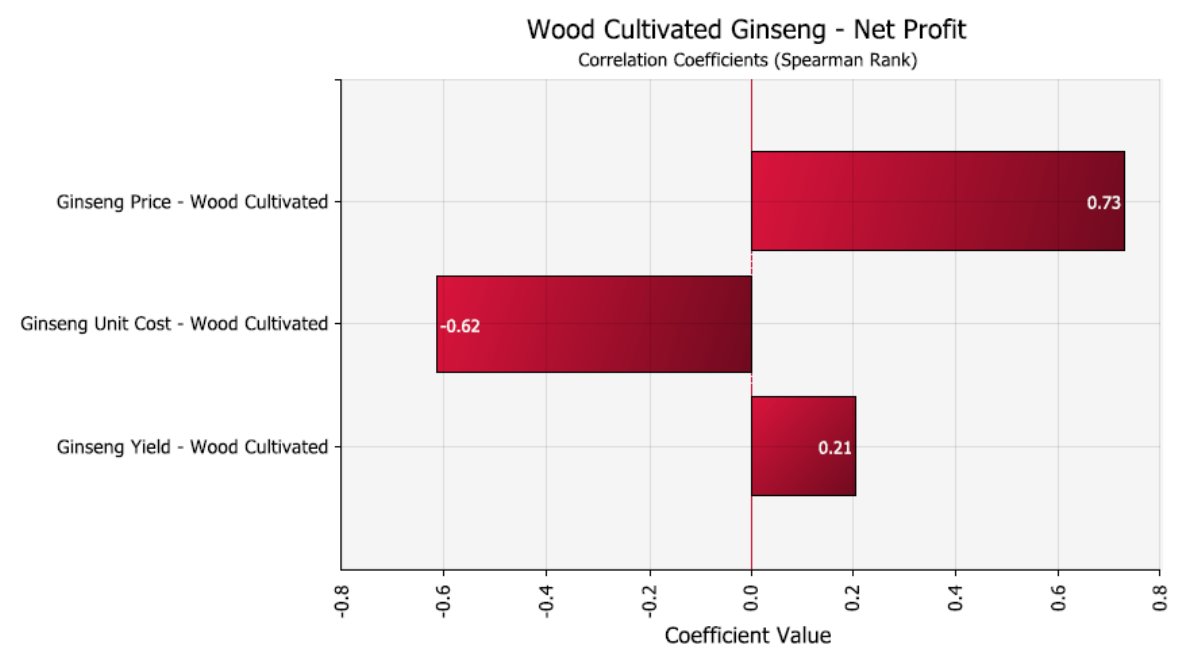

Figure 6. Tornado graph for wood cultivated ginseng

\subsection{Wild Simulated Ginseng}

Figure 7 - 9 shows input distribution of wild simulated ginseng. Accordingly, within $90 \%$ confidence interval, the estimated yield of the wild simulated ginseng ranges from $184-198 \mathrm{~kg} / \mathrm{ha}$ with the mean of $191 \mathrm{~kg} / \mathrm{ha}$. The estimated minimum potential yield was $180 \mathrm{~kg} / \mathrm{ha}$ and the maximum potential yield is $202 \mathrm{~kg} / \mathrm{ha}$. Also under $90 \%$ confidence interval, selling price of ginseng ranges from $\$ 701$ - $\$ 838 / \mathrm{kg}$ while the estimated unit cost of the wild simulated ginseng could range from $\$ 159$ - $\$ 232 / \mathrm{kg}$. The minimum and maximum potential unit cost was $\$ 134$ $\& \$ 237 / \mathrm{kg}$ respectively with mean of $\$ 193 / \mathrm{kg}$.

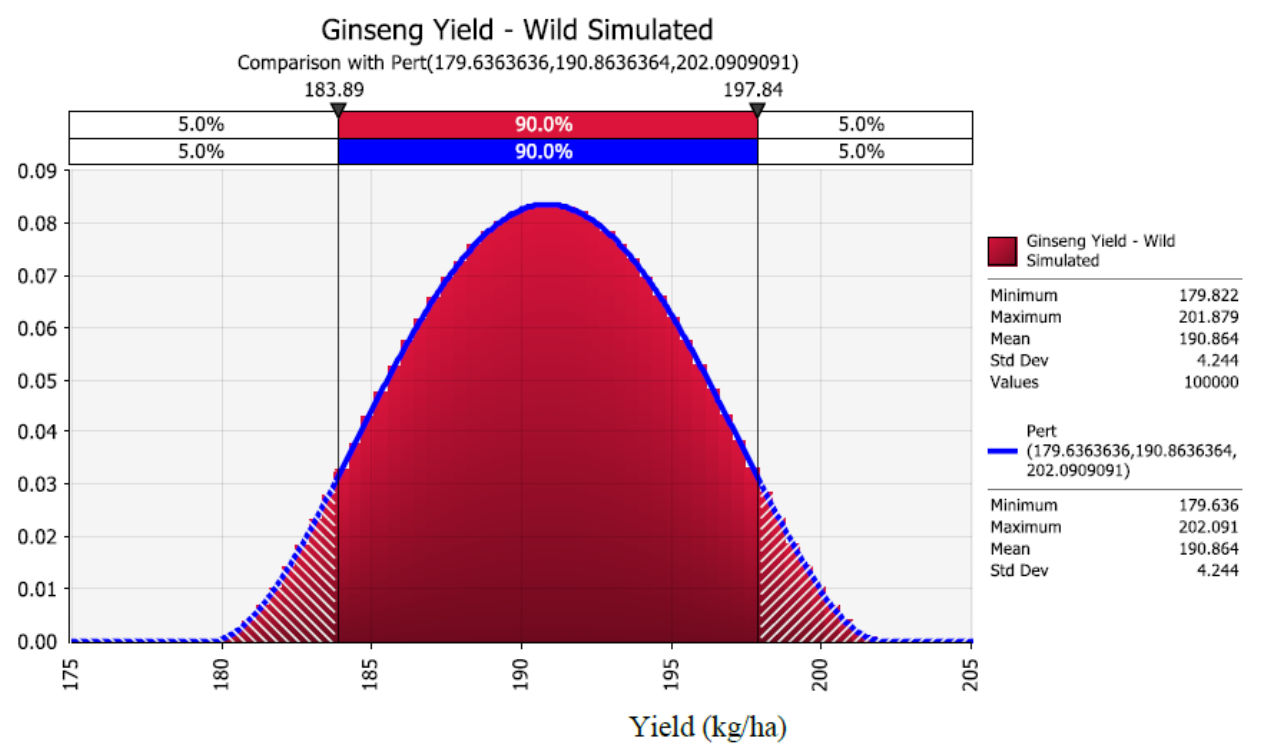

Figure 7. Potential yield distribution of wild simulated ginseng 


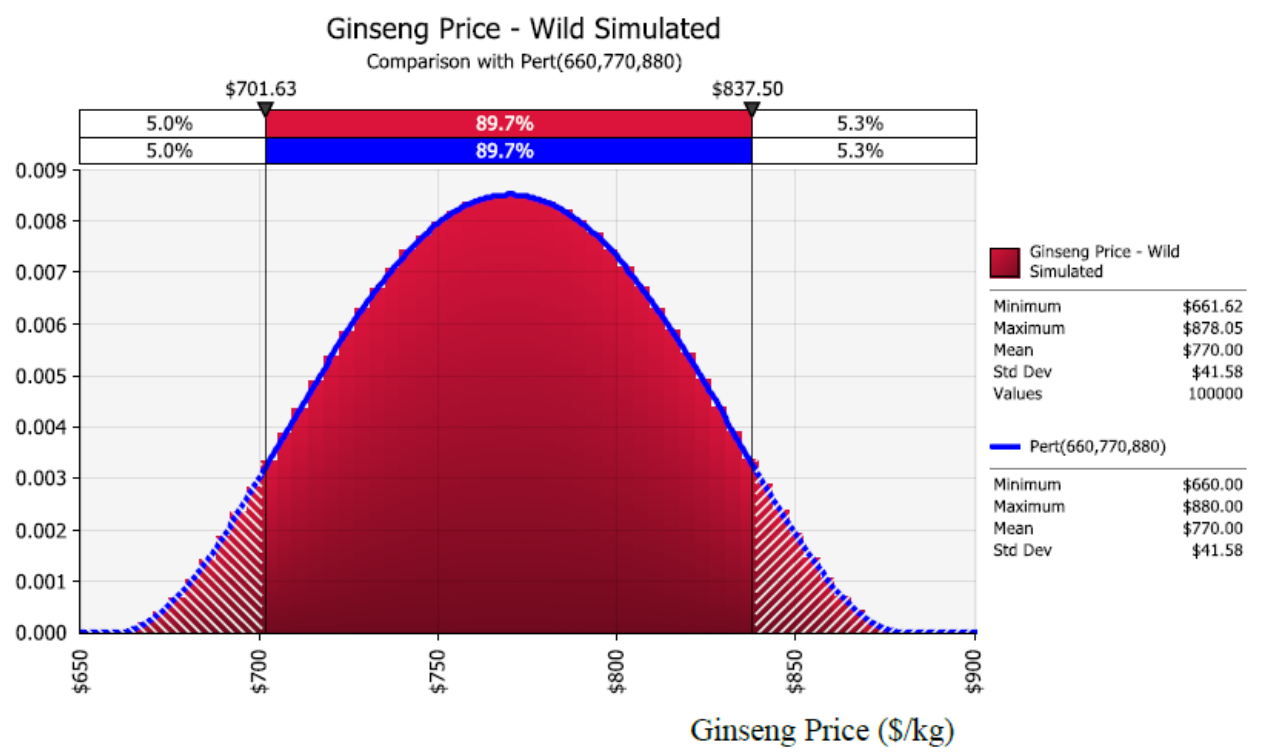

Figure 8. Potential price distribution of wild simulated ginseng

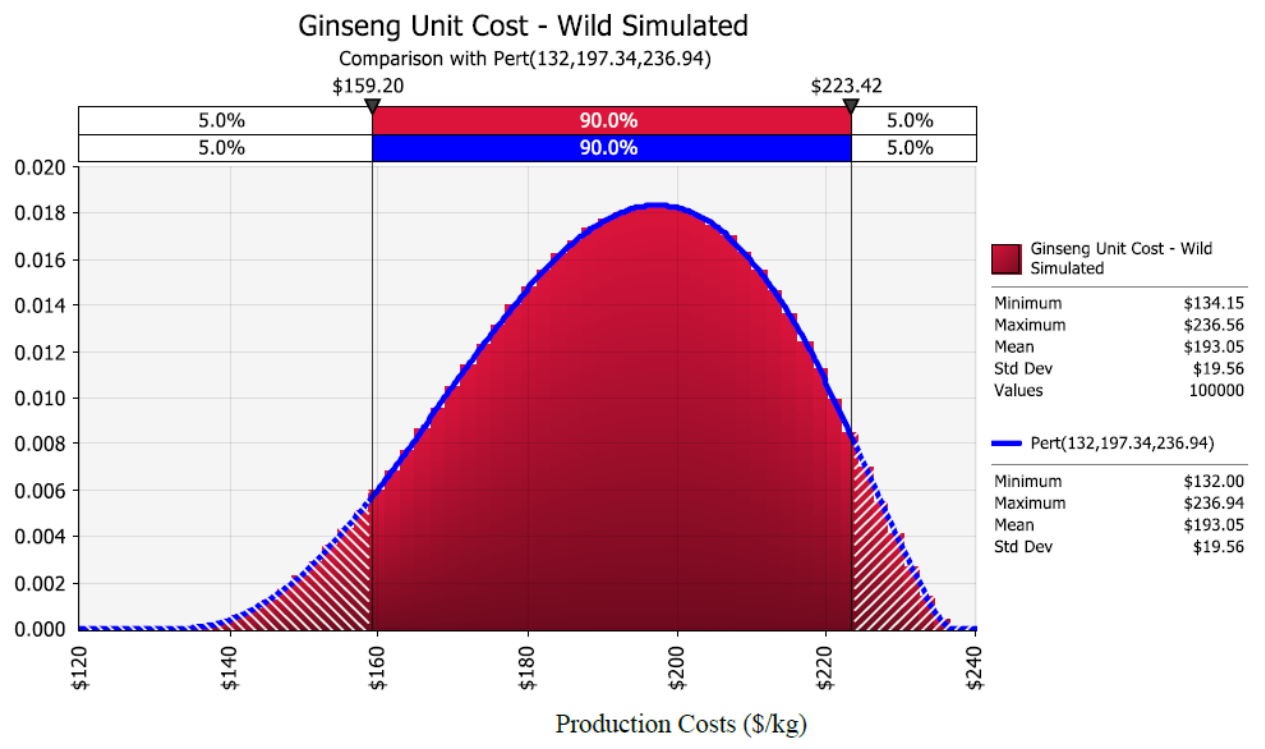

Figure 9. Potential unit cost distribution of wild simulated ginseng

Figure 10 shows the net profit for wild simulated ginseng. According to $90 \%$ confidence interval, the estimated net profit ranges from $\$ 94,200$ and $\$ 124,314 /$ cycle with the mean net return of $\$ 109,168 /$ cycle. The minimum potential net profit was $\$ 79,967$ and the maximum net profit was $\$ 141,740 /$ cycle. 


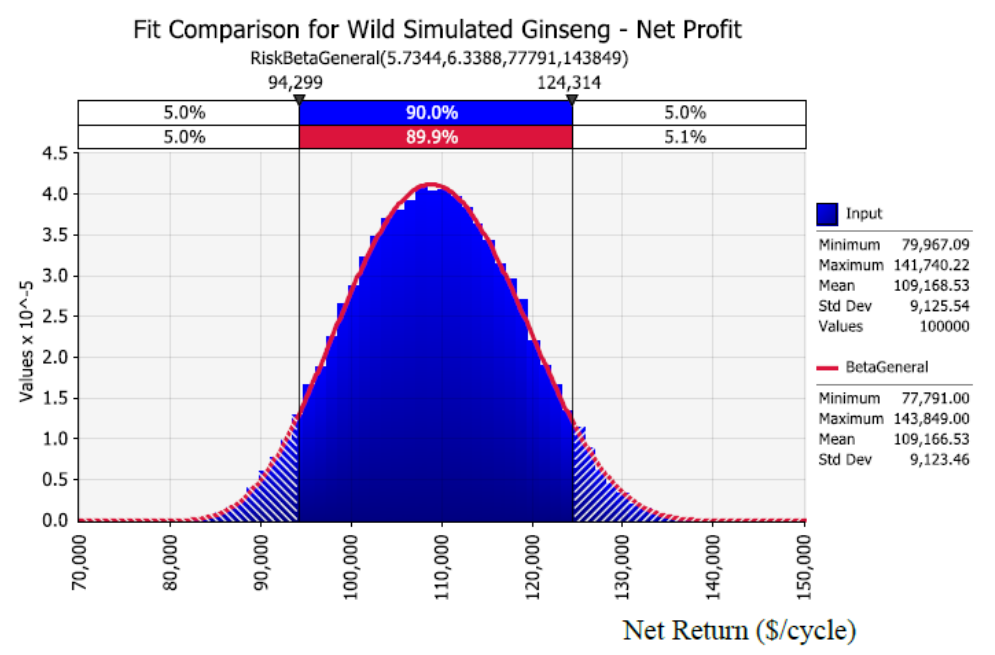

Figure10. Distribution of net return from wild simulated ginseng

Figure 11 shows the correlation between wild simulated ginseng yield, price and unit cost to net profit. Pearson correlation coefficient was $0.26,0.87$ and -0.41 respectively for yield, price and unit costs of production. Unit production costs of ginseng is negatively correlated with net profit. Moreover, negative correlation with net profit shows possibility of lower profit under low yield though lower production is theoretically associated with higher product price. The typical selling price is high at low yield, but decreased yield does not make up to recover the losses. Compared to yield, ginseng price is highly correlated to net return while higher unit costs lower the net return to the producer (Figure 12).

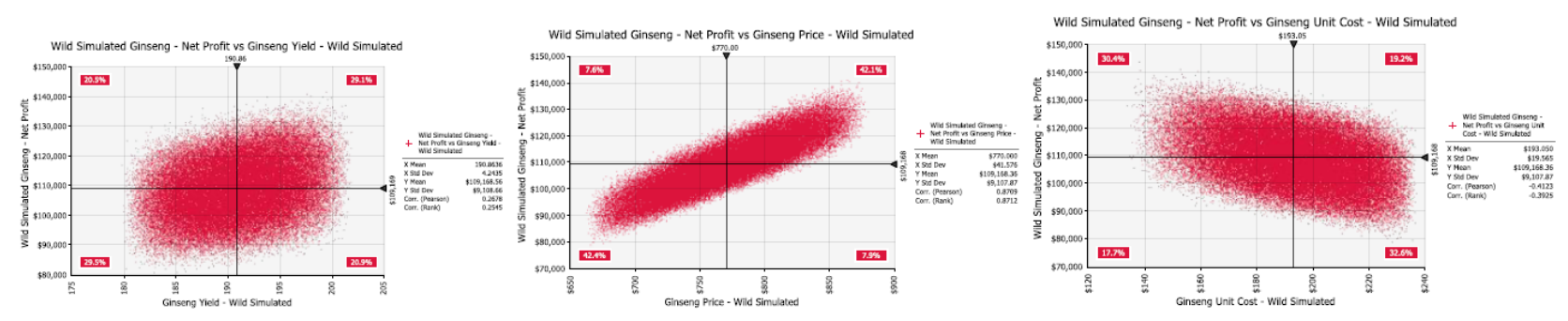

Figure 11. Correlation between net return and stochastic variables in wild simulated ginseng

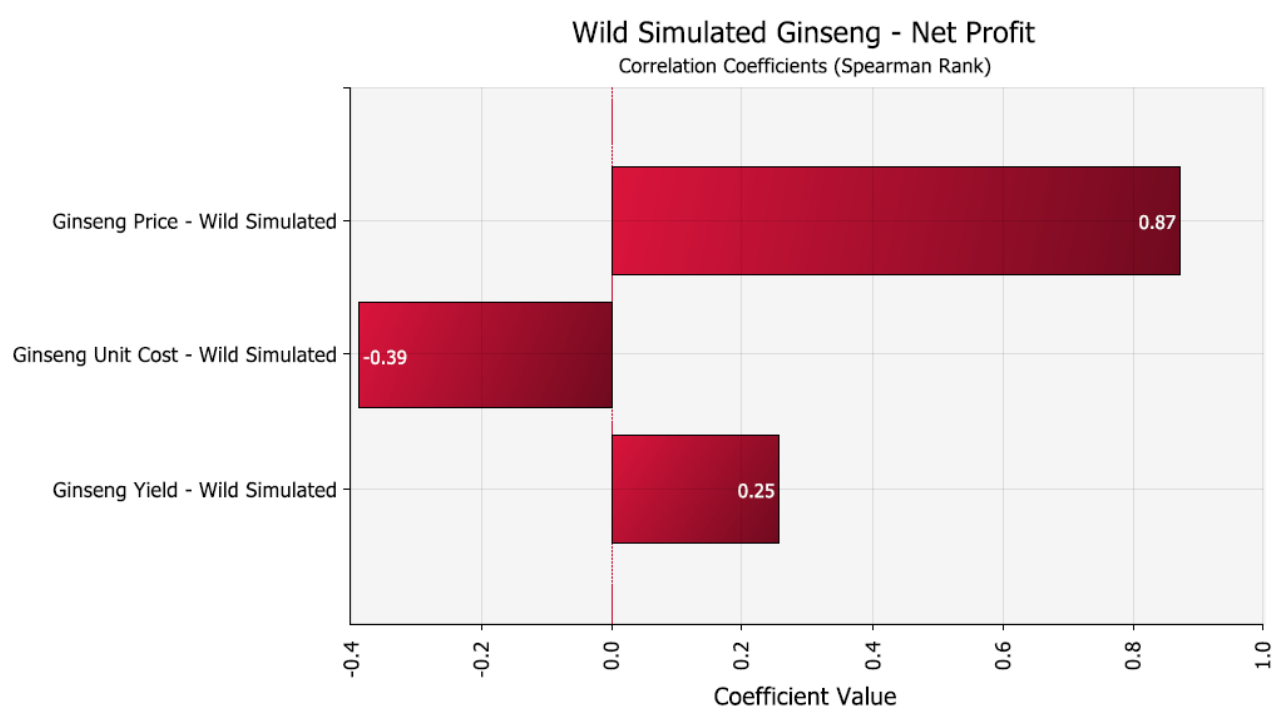

Figure 12. Tornado graph for wild simulated ginseng Conclusion 


\section{Conclusion}

This study was focused on the feasibility of producing American ginseng and its unique benefits to producers. The Monte Carlo simulation was performed to assess the viability of cultivating ginseng under the different cultivating systems. The goal was to place emphasis on potential risk variables that could impact net returns namely, production costs, yields, and price of the product. Information gathered from various sources on key production inputswere used to compare and analyze the economic returns and risks associated with producing ginseng. The findings revealed that among the two production methods, the mean ginseng yield was approximately $741 / \mathrm{kg} \mathrm{ha}^{-1}$ and $191 / \mathrm{kg} \mathrm{ha}^{-1}$ in wood cultivated and wild simulated systems respectively. Although yield is comparatively low, market price of wild simulated ginseng was much higher $(\$ 770 / \mathrm{kg})$ compared to wood cultivated ginseng $(\$ 275)$. The mean net return of wild simulated ginseng was $\$ 109,668 /$ cycle while in wood cultivated system, the mean net return was $\$ 124,816$ per cycle. These results suggest the economic feasibility of investment for ginseng as a long term forest based investment. Although production of ginseng is profitable, there are certain risks involved, and producing ginseng can be a way for forest landowners to utilize their land and subsidize their annual incomes.Most new growers of ginseng are attracted by the potential profits. Since this is a lucrative investment opportunity for forest landowners, there is a need for practical training, resource materials, and outreach materials on ginseng production. There is a need for landowners to have more education and training on the different production systems. The University outreach services could play an important role by designing training programs, demonstration sessions, pilot programs and information needed for growers. In addition, production of ginseng needs support from federal and state agencies to access technical and financial resources needed for growers. This could provide an opportunity to learn and invest on forest income enterprises such as production of ginseng

\section{References}

Arnold, U., \& Yildiz, Ö. (2015). Economic risk analysis of decentralized renewable energy infrastructures-A Monte Carlo Simulation approach. Renewable Energy, 77, 227-239. https://doi.org/10.1016/j.renene.2014.11.059

Axtell, N. (2012). Forest farming key to saving wild ginseng from extinction. Retrieved from http://www.blueridgenow.com/article/20121209/ARTICLES/121209833

Baeg, I., \& So, S. (2013). The world ginseng market and the ginseng (Korea). Journal of Ginseng Research, 27(1), 1-7. https://doi.org/10.5142/jgr.2013.37.1

Beyfuss, R. (1999). Economics and marketing of ginseng. Retrieved from http://www.wvfa.org/pdf/sfi/ginseng.pdf

Cheng, L., \& Mitchell, P. (2009). Status of the Wisconsin ginseng industry. Retrieved from https://www.aae.wisc.edu/pubs/misc/docs/Mitchell.WI.Ginseng.Industry.2009.pdf

Ha, K., Atallah, S., Benjamin, T., Fariee, L., Hoagland, L., \& Woeste, K. (2017). Costs and returns of producing wild-simulated ginseng in established tree plantations. Purdue Extension, FNR-550-W. Retrieved from https://www.fs.fed.us/nrs/pubs/jrnl/2017/nrs_2017_ha_001.pdf

Hankins, A. (2014). Wild-simulated forest farming for ginseng production. Retrieved from http://www.aftaweb.org/latest-newsletter/temporate-agroforester/57-1997-vol-5/january-no-1/23-forest-gins eng-production.html

Hankins, A. (2009). Producing and marketing wild simulated ginseng in forest and agroforestry systems. Retrieved from http://pubs.ext.vt.edu/354/354-312/354-312.html

Harrison, H. C., Parke, J. L., Oelke, E. A., Kaminski, A. R., Hudelson, B. D., Martin, L. J., ... Binning, L. K. (2015). Ginseng. Alternative field crops manual. Retrieved from https://www.hort.purdue.edu/newcrop/afcm/ginseng.html

Kays, J. S. (2004). Alternative income opportunities: Needs of county agents and foresters in the Mid-Atlantic region. Journal of Extension, 42, Article 2RIB6. Retrieved from http://www.joe.org/joe/2004april/rb6.php

Maher, K. (2014). Demand for ginseng boosts prices, tempts poachers; medicinal herb grows wildly in Appalachia and the Midwest. Wall Street Journal. Retrieved from http://www.wsj.com/articles/demand-for-ginseng-boostsprices-tempts-poachers-1410971637

Palisade, (n.d). Monte Carlo simulation. Retrieved from https://www.palisade.com/risk/monte_carlo_simulation.asp 
Punja, Z. K. (2011). American ginseng: research developments, opportunities, and challenges. Journal of Ginseng Research, 35(3), 368-374. https://doi.org/10.5142/jgr.2011.35.3.368

Shyong, F. (2015). American ginseng has a loyal Chinese clientele. Retrieved from http://www.latimes.com/local/california/la-me-adv-ginseng-american-20150301-story.html

USFWS. (n.d). American ginseng. U.S. Fish and Wildlife Service. Retrieved from http://www.fws.gov/international/plants/american-ginseng.html

Vaughn, R., Chamberlain, J., \& Munsell, J., (2011). Growing American ginseng (Panax quinquefolius) in forestlands. Retrieved from http://pubs.ext.vt.edu/354/354-313/354-313.html.

Wallin, C. (2016). Ginseng: A high value crop with long term potential! Retrieved from http://www.profitableplantsdigest.com/ginseng/\#wrap

Workman, S. W., Bannister, M. E., \& Nair, P. K. R. (2003). Agroforestry potential in the Southeastern United States: Perceptions of landowners and extension professionals. Agroforestry Systems, 59, 73-83. https://doi.org/10.1023/A:1026193204801

Yuldashev, F., Illukpitiya, P., Tegegne, F., \& Ekanem, E. (2020). Techno-economic analysis of plantation biomass production and small-scale wood pellet processing for bioenergy market, International Wood Products Journal, 11(4), 173-188. https://doi.org/10.1080/20426445.2020.1816766

\section{Copyrights}

Copyright for this article is retained by the author(s), with first publication rights granted to the journal.

This is an open-access article distributed under the terms and conditions of the Creative Commons Attribution license (http://creativecommons.org/licenses/by/3.0/). 